\title{
Degradation of trans-ferulic acid in acidic aqueous medium by anodic oxidation, electro-Fenton and photoelectro-Fenton
}

Nelly Flores, Ignasi Sirés, José Antonio Garrido, Francesc Centellas, Rosa María Rodríguez, Pere Lluís Cabot, Enric Brillas*

Laboratori d'Electroquímica dels Materials i del Medi Ambient, Departament de Química Física, Facultat de Química, Universitat de Barcelona, Martí i Franquès 1-11, 08028 Barcelona, Spain

Article submitted for publication in Journal of Hazardous Materials

* Corresponding author: Tel.: +34 934021223; fax: +34 934021231

E-mail address: brillas@ub.edu (E. Brillas) 


\section{Abstract}

Solutions of pH 3.0 containing trans-ferulic acid, a phenolic compound in olive oil mill wastewater, have been comparatively degraded by anodic oxidation with electrogenerated $\mathrm{H}_{2} \mathrm{O}_{2}\left(\mathrm{AO}-\mathrm{H}_{2} \mathrm{O}_{2}\right)$, electro-Fenton (EF) and photoelectro-Fenton (PEF). Trials were performed with a BDD/airdiffusion cell, where oxidizing $\bullet \mathrm{OH}$ was produced from water discharge at the BDD anode and/or in the solution bulk from Fenton's reaction between cathodically generated $\mathrm{H}_{2} \mathrm{O}_{2}$ and added catalytic $\mathrm{Fe}^{2+}$. The substrate was very slowly removed by $\mathrm{AO}-\mathrm{H}_{2} \mathrm{O}_{2}$, whereas it was very rapidly abated by EF and PEF, at similar rate in both cases, due to its fast reaction with ${ }^{\bullet} \mathrm{OH}$ in the bulk. The AO$\mathrm{H}_{2} \mathrm{O}_{2}$ process yielded a slightly lower mineralization than EF, which promoted the accumulation of barely oxidizable products like Fe(III) complexes. In contrast, the fast photolysis of these latter species under irradiation with UVA light in PEF led to an almost total mineralization with 98\% total organic carbon decay. The effect of current density and substrate concentration on the performance of all treatments was examined. Several solar PEF (SPEF) trials showed its viability for the treatment of wastewater containing trans-ferulic acid at larger scale. Four primary aromatic products were identified by GC-MS analysis of electrolyzed solutions, and final carboxylic acids like fumaric, acetic and oxalic were detected by ion-exclusion HPLC. A reaction sequence for trans-ferulic acid mineralization involving all the detected products is finally proposed.

Keywords: Anodic oxidation; Electro-Fenton; Oxidation products; Photoelectro-Fenton; transFerulic acid 


\section{Introduction}

The olive oil industry in Mediterranean countries like Spain, Italy, Greece and Portugal supplies about $77 \%$ of the worldwide output of this product. During the extraction of the olive oil, however, a volume of industrial effluents as large as 30 million cubic meters is produced annually in the world. Olive oil mill wastewater (OOMWW) has acidic $\mathrm{pH}$ near 5, high chemical and biochemical oxygen demand up to $110 \mathrm{~g} \mathrm{~L}^{-1}$ and $170 \mathrm{~g} \mathrm{~L}^{-1}$, respectively, and total solids contents up to $150 \mathrm{~g} \mathrm{~L}^{-1}$ [1], which is very harmful for the environment by the negative effects over soil microbial population [2] and aquatic ecosystems [3]. Phenols, lipids, sugars and tannins are the main organic components of OOMWW, representing up to $37 \%$ of the total mass $[4,5]$. One of the most important phenolic compounds is trans-ferulic acid (4-hydroxy-3-methoxycinnamic acid), much more abundant than its cis isomer. trans-Ferulic acid is also present in the plant cell wall of various fruits and vegetables, possesses a high antioxidant activity and low toxicity after oral administration $\left(\mathrm{LD}_{50}=3200 \mathrm{mg} \mathrm{kg}^{-1}\right)$ and has been detected in rivers, lakes and sea sediments [6]. At industrial level, it is used as ingredient in many drug formulations and food additives, being its derivative vanillin of huge commercial importance in the food industry [7]. So far, little information about the degradation of trans-ferulic acid for wastewater treatment is available. Several authors have described its oxidation by pyrilium salt photosensitized with sunlight [8] and advanced oxidation processes (AOPs) such as catalytic wet oxidation [9], heterogeneous Fenton [10] and $\mathrm{TiO}_{2}$ photocatalysis [11], but the use of powerful electrochemical AOPs (EAOPs) for treating water polluted with trans-ferulic acid has not yet been reported.

Over the last two decades, EAOPs have received growing attention for the remediation of wastewater contaminated with biorecalcitrant organics [12-16]. The common feature of these methods is the in situ generation of reactive oxygen species (ROS) such as hydroxyl radical $\left({ }^{\bullet} \mathrm{OH}\right)$, which can attack most organics up to their mineralization (conversion into $\mathrm{CO}_{2}$ and inorganic ions) due to its high standard reduction potential $\left(E^{\mathrm{o}}=2.80 \mathrm{~V} / \mathrm{SHE}\right)$. The most popular EAOP is anodic 
oxidation (AO), also so-called electrochemical oxidation. In AO, a high current density (j) is usually applied to the anode $\mathrm{M}$ of the cell to produce oxidizing physisorbed hydroxyl radical $\mathrm{M}\left({ }^{\bullet} \mathrm{OH}\right)$ as intermediate of water discharge to $\mathrm{O}_{2}$ at the anode surface by reaction (1) [12,17-19]:

$\mathrm{M}+\mathrm{H}_{2} \mathrm{O} \rightarrow \mathrm{M}\left({ }^{\bullet} \mathrm{OH}\right)+\mathrm{H}^{+}+\mathrm{e}^{-}$

When considering the abatement of aromatic organics and even carboxylic acids, the physisorbed $\operatorname{BDD}\left({ }^{\bullet} \mathrm{OH}\right)$ generated at boron-doped diamond (BDD) anode has higher oxidation ability than $\mathrm{M}\left({ }^{\bullet} \mathrm{OH}\right)$ produced by other common anodes [20-23]. This is due to the larger $\mathrm{O}_{2-}$ overpotential of BDD and the low interaction between its surface and $\bullet \mathrm{OH}$, which favors its reaction with organics [12]. At present, the BDD electrode is the preferred anode for AO.

When an undivided cell is used with a carbonaceous cathode able to electrogenerate $\mathrm{H}_{2} \mathrm{O}_{2}$, the process is called $\mathrm{AO}-\mathrm{H}_{2} \mathrm{O}_{2}$, where organics are preferentially destroyed by physisorbed $\mathrm{M}\left({ }^{\bullet} \mathrm{OH}\right)$ along with a minor participation of other ROS such as $\mathrm{H}_{2} \mathrm{O}_{2}$ and its anodic oxidation product $\mathrm{HO}_{2}{ }^{\bullet}$ $[13,14]$. It is well-known that $\mathrm{H}_{2} \mathrm{O}_{2}$ can be efficiently formed from the two-electron reduction of $\mathrm{O}_{2}$ gas via reaction (2) at cathodes such as activated carbon fiber [24], carbon nanotubes [25,26], graphite felt [27], carbon modified with metals or metal oxides nanoparticles [28], carbon felt [2931], carbon-polytetrafluoroethylene (PTFE) $\mathrm{O}_{2}$ or air-diffusion [32-34], and BDD [35,36].

$\mathrm{O}_{2}(\mathrm{~g})+2 \mathrm{H}^{+}+2 \mathrm{e}^{-} \rightarrow \mathrm{H}_{2} \mathrm{O}_{2}$

Another widely used EAOP is the electro-Fenton (EF) process, where a catalytic amount of $\mathrm{Fe}^{2+}$ is added to the solution to enhance the oxidation power of $\mathrm{H}_{2} \mathrm{O}_{2}$ via Fenton's reaction (3) with production of $\mathrm{Fe}^{3+}$ and ${ }^{\bullet} \mathrm{OH}$ in the bulk [29-34]. The optimum $\mathrm{pH}$ for $\mathrm{EF}$ is $\sim 3$ and organic pollutants are then destroyed by both kinds of ROS, $\mathrm{M}\left({ }^{\bullet} \mathrm{OH}\right)$ and ${ }^{\bullet} \mathrm{OH}$. In our laboratory, we have been developing other EAOPs like UVA photoelectro-Fenton (PEF) or solar PEF (SPEF) in which the treated solution is irradiated with either artificial UVA light or sunlight, respectively [37-40]. 
This radiation causes the photoreduction of $\mathrm{Fe}(\mathrm{OH})^{2+}$ species to $\mathrm{Fe}^{2+}$ with ${ }^{\bullet} \mathrm{OH}$ generation via reaction (4), as well as the photodecarboxylation of complexes of Fe(III) with generated carboxylic acids according to reaction (5).

$$
\begin{aligned}
& \mathrm{H}_{2} \mathrm{O}_{2}+\mathrm{Fe}^{2+} \rightarrow \mathrm{Fe}^{3+}+\cdot \mathrm{OH}+\mathrm{OH}^{-} \\
& \mathrm{Fe}(\mathrm{OH})^{2+}+h v \rightarrow \mathrm{Fe}^{2+}+\cdot \mathrm{OH} \\
& \mathrm{Fe}(\mathrm{OOCR})^{2+}+h v \rightarrow \mathrm{Fe}^{2+}+\mathrm{CO}_{2}+\mathrm{R}^{\bullet}
\end{aligned}
$$

This paper presents a comparative study on the degradation of trans-ferulic acid solutions at $\mathrm{pH}$ 3.0 by $\mathrm{AO}-\mathrm{H}_{2} \mathrm{O}_{2}$, EF and PEF using a stirred BDD/air-diffusion tank reactor. The mineralization process was also assessed by SPEF in order to check its potentiality at industrial scale. The effect of $j$ and substrate concentration on the performance of the EAOPs tested was examined to understand the role of the generated hydroxyl radicals and the action of UV light. The decay of trans-ferulic acid and the evolution of some products like vanillin and carboxylic acids were monitored by highperformance liquid chromatography (HPLC). Primary aromatic intermediates were identified by gas chromatography-mass spectrometry (GC-MS). Based on the results obtained, a plausible route for trans-ferulic acid mineralization by EAOPs is proposed.

\section{Experimental}

\subsection{Chemicals}

trans-Ferulic acid (99\% purity) and vanillin (99\% purity) were supplied by Sigma-Aldrich and used without further purification. Fumaric, acetic and oxalic acids were of analytical grade supplied by Merck. Heptahydrated Fe(II) sulfate and anhydrous sodium sulfate were of analytical grade supplied by Fluka. Analytical grade sulfuric acid purchased from Merck was used to adjust the initial solution $\mathrm{pH}$ to 3.0. All the solutions were prepared with high-purity water from a Millipore 
Milli-Q system (resistivity $>18 \mathrm{M} \Omega \mathrm{cm}$ at $25^{\circ} \mathrm{C}$ ). Other chemicals used for analysis were of HPLC or analytical grade provided by Avocado, Fluka and Merck.

\subsection{Electrolytic systems}

All the experiments were performed with an open, undivided, two-electrode cylindrical glass cell of $150 \mathrm{~mL}$ capacity. It was equipped with a double jacket for recirculating water at $35^{\circ} \mathrm{C}$ by means of a Thermo Electron Corporation HAAKE DC 10 thermostat. This working temperature was chosen because it is the maximum value that can be used without significant water evaporation from the solution. All the assays were made under vigorous stirring with a magnetic bar at $700 \mathrm{rpm}$ to ensure the transport of reactants toward/from the electrodes and homogenization. The electrodes were a BDD (deposited onto p-Si) anode purchased from NeoCoat (La-Chaux-de-Fonds, Switzerland) and a carbon-PTFE air-diffusion cathode purchased from E-TEK (Somerset, NJ, USA), both of $3 \mathrm{~cm}^{2}$ geometric area and separated about $1 \mathrm{~cm}$. The cathode was mounted as reported elsewhere [41] and was fed with air pumped at $300 \mathrm{~mL} \mathrm{~min}^{-1}$ for $\mathrm{H}_{2} \mathrm{O}_{2}$ generation from reaction (2). The trials were carried out at constant $j$ provided by an EG\&G Princeton Applied Research 273A potentiostat-galvanostat.

Solutions of $100 \mathrm{~mL}$ containing trans-ferulic acid and $0.05 \mathrm{M} \mathrm{Na}_{2} \mathrm{SO}_{4}$ as background electrolyte at $\mathrm{pH} 3.0$ were comparatively treated by $\mathrm{AO}-\mathrm{H}_{2} \mathrm{O}_{2}$, EF and PEF. In the two latter EAOPs, $0.50 \mathrm{mM} \mathrm{Fe}{ }^{2+}$ was added as catalyst since this content has been found optimal for many organics degraded under similar conditions [37-40]. For PEF, a Philips TL/6W/08 fluorescent black light blue tube of $\lambda_{\max }=360 \mathrm{~nm}$ with average power density of $5 \mathrm{~W} \mathrm{~m}^{-2}$, determined with a Kipp\&Zonen CUV $5 \mathrm{UV}$ radiometer, was placed at $8 \mathrm{~cm}$ above the solution surface. Some experiments were also performed by SPEF upon direct exposition of the cell to sunlight irradiation in clear and sunny days of the summer 2015 in our laboratory of Barcelona (latitude: 41 ${ }^{\circ} 23^{\prime} \mathrm{N}$, longitude: $2^{\circ} 9^{\prime} \mathrm{E}$ ). The average UV solar irradiation intensity from 300 to $400 \mathrm{~nm}$ was about $30 \mathrm{~W}$ $\mathrm{m}^{-2}$, as measured on the radiometer. Before starting the experiments, the surfaces of the anode and 
cathode were cleaned and activated, respectively, under polarization in $100 \mathrm{~mL}$ of a $0.05 \mathrm{M} \mathrm{Na}_{2} \mathrm{SO}_{4}$ solution at $100 \mathrm{~mA} \mathrm{~cm}^{-2}$ for $180 \mathrm{~min}$.

\subsection{Apparatus and analytical methods}

The solution pH was measured on a Crison GLP 22 pH-meter. For total organic carbon (TOC) measurements, samples were withdrawn from treated solutions, filtered with $0.45 \mu \mathrm{m}$ PTFE filters purchased from Whatman and directly injected into a Shimadzu VCSN TOC analyzer, obtaining reproducible values with $\pm 1 \%$ accuracy. From these data and considering that the total mineralization of trans-ferulic acid involves its conversion into $\mathrm{CO}_{2}$ as follows:

$\mathrm{C}_{10} \mathrm{H}_{10} \mathrm{O}_{4}+16 \mathrm{H}_{2} \mathrm{O} \rightarrow 10 \mathrm{CO}_{2}+42 \mathrm{H}^{+}+42 \mathrm{e}^{-}$

the mineralization current efficiency (MCE) for each assay was estimated from Eq. (7) [37]:

$\operatorname{MCE}(\%)=\frac{n F V \triangle(\text { TOC })_{\exp }}{4.32 \times 10^{7} \text { m It }} \times 100$

where $n$ is the number of electrons related to the mineralization process (42 $\mathrm{e}^{-}$according to reaction (6)), $F$ is the Faraday constant (96487 $\mathrm{C} \mathrm{mol}^{-1}$ ), $V$ is the solution volume (L), $\Delta(\text { TOC })_{\exp }$ is the experimental TOC abatement $\left(\mathrm{mg} \mathrm{C} \mathrm{L}^{-1}\right), 4.32 \times 10^{7}$ is a conversion factor (3600 s h${ }^{-1} \times 12000 \mathrm{mg} \mathrm{C} \mathrm{mol}^{-1}$ ), $m$ is the number of carbon atoms of trans-ferulic acid (10 C atoms), $I$ is the current (A) and $t$ is the electrolysis time (h).

Treated solutions were analyzed by reversed-phase HPLC using a Waters 600 LC equipped with a BDS Hypersil C18 $6 \mu \mathrm{m}, 250 \mathrm{~mm}$ x $4.6 \mathrm{~mm}$, column at $35{ }^{\circ} \mathrm{C}$ and coupled to a Waters 996 photodiode array detector. In the EF and PEF assays, the aqueous samples were diluted with acetonitrile to stop the degradation process and then filtered with $0.45 \mu \mathrm{m}$ PTFE filters from Whatman. In all the measurements, $10 \mu \mathrm{L}$ aliquots were injected into the $\mathrm{LC}$ and a $80 \%$ (v/v) acetonitrile/water mixture was eluted at $0.8 \mathrm{~mL} \mathrm{~min}^{-1}$ as mobile phase. The chromatograms exhibited two well-defined peaks at retention time $\left(t_{\mathrm{r}}\right)$ of $3.37 \mathrm{~min}$ for trans- 
ferulic acid and $t_{\mathrm{r}}=3.89$ min for vanillin, monitored at $\lambda$ of 323 and $229 \mathrm{~nm}$, respectively. Generated carboxylic acids were detected by ion-exclusion HPLC using the above LC fitted with a Bio-Rad Aminex HPX 87H, $300 \mathrm{~mm} \times 7.8 \mathrm{~mm}$, column at $35{ }^{\circ} \mathrm{C}$ and the photodiode array detector selected at $\lambda=210 \mathrm{~nm}$. Aliquots of $10 \mu \mathrm{L}$ were also injected into the $\mathrm{LC}$ and the mobile phase was $4 \mathrm{mM} \mathrm{H}_{2} \mathrm{SO}_{4}$ at $0.6 \mathrm{~mL} \mathrm{~min}^{-1}$. The chromatograms displayed peaks related to oxalic $\left(t_{\mathrm{r}}=6.9 \mathrm{~min}\right)$, acetic $\left(t_{\mathrm{r}}=14.9 \mathrm{~min}\right)$ and fumaric $\left(t_{\mathrm{r}}=15.6 \mathrm{~min}\right)$ acids.

The primary aromatic products of trans-ferulic acid were identified by electrolyzing $100 \mathrm{~mL}$ of a $0.834 \mathrm{mM}$ substrate solution at $33.3 \mathrm{~mA} \mathrm{~cm}{ }^{-2}$ by $\mathrm{AO}-\mathrm{H}_{2} \mathrm{O}_{2}$. Independent electrolyses were run up to 30 and 90 min and the organic components of the remaining solutions were extracted out with $\mathrm{CH}_{2} \mathrm{Cl}_{2}(3 \times 25 \mathrm{~mL})$. Each organic fraction was dried over anhydrous $\mathrm{Na}_{2} \mathrm{SO}_{4}$, filtered and its volume reduced to about $1 \mathrm{~mL}$ to be further analyzed by GC-MS using a NIST05-MS library to interpret the mass spectra. GC-MS analysis was performed by coupling a 6890N GC and a 5975C MS from Agilent Technologies, operating in EI mode at $70 \mathrm{eV}$. The GC was fitted with either a non-polar Agilent J\&W HP-5ms or a polar HP INNOWax column, both of $0.25 \mu \mathrm{m}$, $30 \mathrm{~m} \times 0.25$ mm. The temperature ramp was: $36{ }^{\circ} \mathrm{C}$ for $1 \mathrm{~min}, 5{ }^{\circ} \mathrm{C} \mathrm{min}{ }^{-1}$ up to $300{ }^{\circ} \mathrm{C}$ or $250{ }^{\circ} \mathrm{C}$ for the nonpolar or polar column, respectively, and hold time $10 \mathrm{~min}$. The temperature of the inlet, source and transfer line was 250, 230 and $280{ }^{\circ} \mathrm{C}$ for the non-polar column and 250,230 and $250{ }^{\circ} \mathrm{C}$ for the polar one.

\section{Results and discussion}

\subsection{Decay of trans-ferulic acid by $\mathrm{AO}-\mathrm{H}_{2} \mathrm{O}_{2}, \mathrm{EF}$ and PEF}

A first series of trials was made by treating $100 \mathrm{~mL}$ of $0.834 \mathrm{mM}$ trans-ferulic acid solutions in $0.05 \mathrm{M} \mathrm{Na}_{2} \mathrm{SO}_{4}$ at $\mathrm{pH} 3.0$ by the different EAOPs to determine the decay kinetics of the substrate by reversed-phase HPLC. As a preliminary study, it was found that the substrate concentration of such solutions remained unchanged under a 6 W UVA irradiation in the absence of applied current, as 
expected if this compound is not directly photolyzed by UVA radiation (data not shown). For the experiments using $\mathrm{AO}-\mathrm{H}_{2} \mathrm{O}_{2}$ without catalyst, as well as for $\mathrm{EF}$ and $\mathrm{PEF}$ with $0.50 \mathrm{mM} \mathrm{Fe} \mathrm{C}^{2+}$, the solution $\mathrm{pH}$ dropped slightly from 3.0 to a final value near 2.7-2.8 after 360 min electrolysis, probably due to the generation of acidic products like final carboxylic acids [37-40].

Fig. 1a depicts a very slow decay of trans-ferulic acid by $\mathrm{AO}-\mathrm{H}_{2} \mathrm{O}_{2}$, attaining $95 \%$ removal in 360 min. This means that this compound reacts very slowly with generated ROS, preferentially with $\mathrm{BDD}\left({ }^{\bullet} \mathrm{OH}\right)$ originated from reaction (1). In contrast, Fig. 1b highlights a much faster abatement of trans-ferulic acid by EF and PEF, disappearing in about 15 and 10 min, respectively. The large acceleration can be ascribed to its very fast reaction in the bulk with • $\mathrm{OH}$ formed from Fenton's reaction (3) compared with the confined reaction taking place with $\mathrm{BDD}\left({ }^{\bullet} \mathrm{OH}\right)$ near the anode. The slight increase in decay rate for PEF compared to EF suggests a very small participation of the photolytic reaction (4) to induce the production of higher amounts of $\bullet \mathrm{OH}$ in the bulk.

The inset panels of Figs. 1a and b show the good linear fittings obtained for a pseudo-firstorder kinetic analysis of the above concentration decays. This behavior suggests the generation of a steady concentration of $\mathrm{BDD}\left({ }^{\bullet} \mathrm{OH}\right)$ and/or ${ }^{\bullet} \mathrm{OH}$ during all treatments. Table 1 collects the apparent rate constants $\left(k_{1}\right)$ and their excellent square regression coefficients $\left(R^{2}\right)$ found for these assays. As can be seen, the $k_{1}$ value is quite similar in EF and PEF and approximately 3 orders of magnitude higher than that in $\mathrm{AO}-\mathrm{H}_{2} \mathrm{O}_{2}$, confirming that in the two former EAOPs, trans-ferulic acid is slowly oxidized by $\mathrm{BDD}\left({ }^{\bullet} \mathrm{OH}\right)$ and much more quickly by ${ }^{\bullet} \mathrm{OH}$ in the bulk.

The kinetic study of the trans-ferulic acid decay was extended to lower concentrations of 0.167 and $0.417 \mathrm{mM}$ operating at $33.3 \mathrm{~mA} \mathrm{~cm}$. Shorter time was needed for total removal of the substrate as the organic load decreased. For the PEF process, for example, the trans-ferulic acid disappeared at $10 \mathrm{~min}$ for $0.834 \mathrm{mM}$, but after only $7 \mathrm{~min}$ for $0.167 \mathrm{mM}$. According to this tendency, the good pseudo-first-order kinetics obtained for all the EAOPs showed an increasing $k_{1}$ value, as can be seen in Table 1 . This behavior clearly indicates that the kinetic decay does not 
actually obey a true pseudo-first-order reaction, since the same $k_{1}$ value should be determined regardless of the substrate content. Since quite similar amounts of $\mathrm{BDD}\left({ }^{\bullet} \mathrm{OH}\right)$ and/or ${ }^{\bullet} \mathrm{OH}$ are generated in each EAOP at $33.3 \mathrm{~mA} \mathrm{~cm}^{-2}$ when the organic matter content rises, a larger proportion of radicals is expected to react with the oxidation products formed and hence, a smaller quantity of them reacts with trans-ferulic acid, thus decelerating its abatement as experimentally found.

\subsection{Mineralization of trans-ferulic acid solutions by $\mathrm{AO}-\mathrm{H}_{2} \mathrm{O}_{2}, \mathrm{EF}$ and $\mathrm{PEF}$}

The mineralization of $0.834 \mathrm{mM}$ trans-ferulic acid solutions at $\mathrm{pH} 3.0$ was comparatively assessed for $\mathrm{AO}-\mathrm{H}_{2} \mathrm{O}_{2}$, EF and PEF at $j=33.3 \mathrm{~mA} \mathrm{~cm}^{-2}$ by monitoring their TOC abatement. Fig. 2a shows a small but continuous mineralization under $\mathrm{AO}-\mathrm{H}_{2} \mathrm{O}_{2}$ conditions, only achieving $72 \%$ TOC removal after 360 min of electrolysis. A much quicker TOC decay can be observed for EF, where TOC was finally reduced by $80 \%$. Note that the mineralization process was very fast up to 90 min of EF because of the efficient action of $\bullet \mathrm{OH}$, whereas it was progressively decelerated at longer time suggesting the formation of more recalcitrant products, like Fe(III)-carboxylate complexes, which are refractory to ${ }^{\bullet} \mathrm{OH}$ and slowly attacked by $\mathrm{BDD}\left({ }^{\bullet} \mathrm{OH}\right)$ [14]. In contrast, Fig. 2a evidences a very positive effect of UVA light in the PEF process since it is able to remove 95\% TOC in 180 min, therefore attaining an almost total mineralization with 98\% TOC reduction at 360 min. This large enhancement can be related to the photolysis of intermediates involving, for example, the photodecomposition of Fe(III)-carboxylate species via reaction (5) [14-16]. These results clearly indicate that the oxidation ability of the EAOPs grows in the sequence $\mathrm{AO}-\mathrm{H}_{2} \mathrm{O}_{2} \leq \mathrm{EF}<\mathrm{PEF}$.

Fig. 2b depicts the MCE values calculated from Eq. (7) for the trends given in Fig. 2a. As expected, the current efficiency rose as more oxidizing EAOPs were tested, although this behavior was more apparent at short electrolysis time, because the mineralization rate was particularly influenced by the oxidation with $\bullet \mathrm{OH}$ and the photolytic action of UVA light. In EF and, especially, the powerful PEF, the MCE values decayed dramatically from $43 \%$ and $81 \%$ at the beginning of the treatments to $13 \%$ and $15 \%$ at $360 \mathrm{~min}$, respectively. This fall of current efficiency can be 
associated not only with the generation of more recalcitrant oxidation products but also with the gradual disappearance of organic matter $[12,39,40]$. In contrast, the current efficiency acquired a practically constant value of $11 \%-12 \%$ during the $\mathrm{AO}-\mathrm{H}_{2} \mathrm{O}_{2}$ run, suggesting a steady mineralization rate of intermediates upon oxidation by $\mathrm{BDD}\left({ }^{\bullet} \mathrm{OH}\right)$ alone.

Since $j$ determines the amount of hydroxyls radicals produced in the EAOPs, the effect of this parameter between 16.7 and $100 \mathrm{~mA} \mathrm{~cm}{ }^{-2}$ on the mineralization of $0.834 \mathrm{mM}$ trans-ferulic acid solutions was investigated. Table 1 collects the percentage of TOC removed after 360 min of all these treatments. For $\mathrm{AO}-\mathrm{H}_{2} \mathrm{O}_{2}$ and $\mathrm{EF}$, the mineralization degree underwent a progressive rise when $j$ increased, as a result of the gradually greater production of oxidizing hydroxyl radicals. This means that the concomitant increase in rate of reaction (1) yields higher quantities of $\mathrm{BDD}\left({ }^{\bullet} \mathrm{OH}\right)$ in AO- $\mathrm{H}_{2} \mathrm{O}_{2}$ while the enhancement of reaction (2) favors the larger accumulation of $\mathrm{H}_{2} \mathrm{O}_{2}$ that consequently accelerates the ${ }^{\bullet} \mathrm{OH}$ formation from Fenton's reaction (3) in EF. Note that EF was more powerful than $\mathrm{AO}-\mathrm{H}_{2} \mathrm{O}_{2}$ only up to $33.3 \mathrm{~mA} \mathrm{~cm}$, with higher $j$ values leading to a similar final TOC removal in both cases. This suggests the formation of final products in EF, probably complexes with $\mathrm{Fe}(\mathrm{III})$, that are difficultly destroyed by $\mathrm{BDD}\left({ }^{\bullet} \mathrm{OH}\right)$ and/or ${ }^{\bullet} \mathrm{OH}$, whereas the final species formed in $\mathrm{AO}-\mathrm{H}_{2} \mathrm{O}_{2}$ can be more easily removed by increasing amounts of $\mathrm{BDD}\left({ }^{\bullet} \mathrm{OH}\right)$. In PEF, Fig. 3a highlights a short activation time at the beginning of the electrolysis at $16.7 \mathrm{~mA} \mathrm{~cm}^{-2}$, followed by a quick TOC decay to reach $96 \%$ reduction at $180 \mathrm{~min}$, whereby the mineralization was strongly inhibited to be reduced by $98 \%$ at 360 min. However, a similar but faster TOC decay can be observed for greater $j$ values, achieving up to 95-97\% TOC reduction in 180 min. This is indicative of a very quick photolytic destruction of intermediates that are very slowly destroyed by $\mathrm{BDD}\left({ }^{\bullet} \mathrm{OH}\right)$ and/or ${ }^{\bullet} \mathrm{OH}$. UVA irradiation is then so potent that, at $33.3 \mathrm{~mA} \mathrm{~cm}^{-2}$, sufficient amounts of hydroxyl radicals are produced to yield products that can be completely photolyzed.

The current efficiency for each EAOP always decreased when $j$ increased. This tendency can be easily deduced from the MCE values corresponding to the end of all trials, as listed in the last 
column of Table 1. Fig. 3b exemplifies the MCE-time plots obtained for the powerful PEF process, showing the concomitant drop of current efficiency for all $j$ values. The anomalous behavior observed in this figure up to $60-90 \mathrm{~min}$ at $16.7 \mathrm{~mA} \mathrm{~cm}-2$ is due to the induction period required under such a low $j$ value, probably because the poor production of hydroxyl radicals entails a slower appearance of intermediates that can be rapidly photolyzed by UVA light.

The decay in MCE at higher $j$ is contrary to the quicker TOC removal found. This behavior is typical of EAOPs and can be ascribed to the destruction of the excess of generated hydroxyl radicals by non-oxidizing wasting reactions. They include the anodic oxidation of physisorbed $\mathrm{BDD}\left({ }^{\bullet} \mathrm{OH}\right)$ radicals to $\mathrm{O}_{2}$ by reaction (8) and the destruction of $\bullet \mathrm{OH}$ by $\mathrm{H}_{2} \mathrm{O}_{2}$ and $\mathrm{Fe}^{2+}$ from reactions (9) and (10), respectively, along with the larger enhancement of the anodic formation of other weaker oxidants such as ozone by reaction (11) and $\mathrm{S}_{2} \mathrm{O}_{8}{ }^{2-}$ ion from $\mathrm{SO}_{4}{ }^{2-}$ ion by reaction (12), thus inhibiting the $\mathrm{H}_{2} \mathrm{O}$ discharge from reaction (1) [12-16].

$2 \mathrm{BDD}\left({ }^{\bullet} \mathrm{OH}\right) \rightarrow 2 \mathrm{BDD}+\mathrm{O}_{2}+2 \mathrm{H}^{+}+2 \mathrm{e}^{-}$

$\mathrm{H}_{2} \mathrm{O}_{2}+\cdot \mathrm{OH} \rightarrow \mathrm{HO}_{2}^{\bullet}+\mathrm{H}_{2} \mathrm{O}$

$\mathrm{Fe}^{2+}+\cdot \mathrm{OH} \rightarrow \mathrm{Fe}^{3+}+\mathrm{OH}^{-}$

$3 \mathrm{H}_{2} \mathrm{O} \rightarrow \mathrm{O}_{3}+6 \mathrm{H}^{+}+6 \mathrm{e}^{-}$

$2 \mathrm{SO}_{4}^{2-} \rightarrow \mathrm{S}_{2} \mathrm{O}_{8}^{2-}+2 \mathrm{e}^{-}$

The influence of the substrate concentration in the range $0.167-1.668 \mathrm{mM}$ on the mineralization of trans-ferulic solutions upon application of the EAOPs was examined at the best $j$ of $33.3 \mathrm{~mA} \mathrm{~cm}^{-2}$ found for PEF. A look at Table 1 reveals that TOC removals of $67 \%-74 \%$ and slightly higher values of $74 \%-80 \%$ were achieved in $\mathrm{AO}-\mathrm{H}_{2} \mathrm{O}_{2}$ and $\mathrm{EF}$, respectively. In fact, AO$\mathrm{H}_{2} \mathrm{O}_{2}$ showed lower oxidation ability than EF up to $0.843 \mathrm{mM}$, whereas both methods had a similar mineralization power for higher substrate concentrations. Despite the similar mineralization attained 
in each of these EAOPs regardless of the trans-ferulic content, a careful inspection of Table 1 indicates a progressive increase of the corresponding final current efficiency when raising the initial substrate amount. For $\mathrm{AO}-\mathrm{H}_{2} \mathrm{O}_{2}$, for example, the MCE grew from $2.3 \%$ at $0.164 \mathrm{mM}$ to $21 \%$ at $1.668 \mathrm{mM}$. As mentioned above, similar quantities of hydroxyl radicals are expected to be generated in each EAOP at a given $j$ and thus, one can infer that a larger organic matter content favors the reaction of $\mathrm{BDD}\left({ }^{\bullet} \mathrm{OH}\right)$ and/or ${ }^{\bullet} \mathrm{OH}$ with oxidation products, thereby decelerating their wasting reactions (8)-(12). This also takes place for the PEF process, as can be deduced from the data of Table 1. Fig. 4a depicts the very high oxidation power of this method, which was even able to yield a $98 \%$ mineralization for the most concentrated $1.668 \mathrm{mM}$ solution due to the additional quick photodecomposition of intermediates under UVA irradiation. The corresponding MCE-time plots of Fig. 4b highlight again the drop of the current efficiency at prolonged electrolysis because of the gradual generation of highly recalcitrant products and the loss of organic matter, as stated above. The MCE value increased with increasing substrate content as well, due to the larger oxidation with hydroxyl radicals to generate more products that can be rapidly photolyzed. At the end of these PEF treatments, the current efficiency varied from $2.9 \%$ for $0.164 \mathrm{mM}$ to a high value of $31 \%$ for $1.668 \mathrm{mM}$. All these findings allow concluding that the treatment of more concentrated solutions largely upgrades the mineralization process of trans-ferulic acid solutions.

\subsection{SPEF treatment of trans-ferulic acid solutions}

In view of the excellent results found for the PEF process, some experiments were made by degrading trans-ferulic acid solutions by SPEF at several $j$ values for $180 \mathrm{~min}$. Fig. 5a presents the quick TOC abatement found in these trials, which was even much faster than that obtained by PEF under comparable conditions (see Figs. 3a and 4a) because of the higher UV intensity supplied by sunlight. As can be observed, a $0.834 \mathrm{mM}$ substrate solution at $33.3 \mathrm{~mA} \mathrm{~cm}{ }^{-2}$ reached $93 \%$ mineralization in $120 \mathrm{~min}$, without further TOC removal at longer time. At $100 \mathrm{~mA} \mathrm{~cm}{ }^{-2}$, the higher production of hydroxyl radicals along with the quicker photolysis of oxidation products allowed 
attaining equal final TOC decay in only about $60 \mathrm{~min}$. At that time, a $0.417 \mathrm{mM}$ solution treated at $33.3 \mathrm{~mA} \mathrm{~cm}^{-2}$ already reached a steady mineralization with near $84 \%$ TOC reduction. The fact that SPEF yielded a smaller final mineralization degree than PEF at the same $j$ values (see Fig. 5a and Table 1) indicates that the quicker photolysis of some intermediates by the more potent sunlight led to a larger accumulation of highly recalcitrant products.

Fig. 5b depicts that the MCE values for the SPEF trials of Fig. 5a showed the same trends already discussed for the other EAOPs, such as a gradual drop of current efficiency (i) at longer electrolysis, (ii) when the initial substrate concentration becomes too low and by (iii) at higher $j$, owing to the reasons pointed out above. For the best SPEF treatment of a $0.834 \mathrm{mM}$ trans-ferulic acid solution at $33.3 \mathrm{~mA} \mathrm{~cm}{ }^{-2}$, a 44\% MCE was found at 120 min when the maximum 93\% TOC removal was reached.

The aforementioned findings corroborate the viability of SPEF for the remediation of wastewater containing trans-ferulic acid at industrial level. The method becomes more efficient using concentrated solutions and operating at a low $j$ such as $33.3 \mathrm{~mA} \mathrm{~cm}{ }^{-2}$.

\subsection{Identification and evolution of aromatic products and generated carboxylic acids}

Table 2 summarizes the characteristics of the four primary aromatic products of trans-ferulic acid (1) detected by GC-MS at 30 and 90 min of electrolysis of a $0.834 \mathrm{mM}$ solution of $\mathrm{pH} 3.0$ by AO- $\mathrm{H}_{2} \mathrm{O}_{2}$ at $33.3 \mathrm{~mA} \mathrm{~cm}{ }^{-2}$. Compound $\mathbf{2}$ arises from the decarboxylation of $\mathbf{1}$, whereas compounds 3-5 are produced by its further oxidation. It is noticeable that the generation of compound $\mathbf{5}$ (vanillin) has also been reported during the degradation of trans-ferulic acid by ${ }^{\circ} \mathrm{OH}$ radicals originated in $\mathrm{TiO}_{2}$ photocatalysis [11].

On the basis of the above GC-MS results, the change of the concentration of compound 5 during the degradation of $0.834 \mathrm{mM}$ trans-ferulic acid solutions at $33.3 \mathrm{~mA} \mathrm{~cm}{ }^{-2}$ under the conditions of Fig. 1 was followed from its characteristic peak recorded by reversed-phase HPLC. Only traces of this product $(<0.005 \mathrm{mM})$ were found under $\mathrm{AO}-\mathrm{H}_{2} \mathrm{O}_{2}$ treatment, suggesting that it 
was destroyed by $\operatorname{BDD}\left({ }^{\bullet} \mathrm{OH}\right)$ and produced from the oxidation of $\mathbf{1}$ at a similar rate. This hypothesis was confirmed from the rapid accumulation and disappearance of $\mathbf{5}$ under EF and PEF conditions, as shown in Fig. 6a. A similar content of this product can be observed during both treatments, with a maximum value of $0.0030 \mathrm{mM}$ at ca. $6 \mathrm{~min}$ and almost total removal at $15 \mathrm{~min}$, i.e., when the parent molecule $\mathbf{1}$ had been just removed (see Fig. 1b). These results point to a very quick reaction of $\mathbf{1}$ and its primary aromatic products with ${ }^{\bullet} \mathrm{OH}$ in the bulk, whereas the subsequent products are much more slowly destroyed by hydroxyl radicals, therefore decelerating the mineralization process (see Fig. 2a)

It is well known that the cleavage of the benzene ring of aromatic compounds originates linear products that evolve to short aliphatic carboxylic acids [13-17]. To explore this possibility for transferulic acid mineralization, the solutions treated under the conditions of Fig. 2 were analyzed by ion-exclusion HPLC. Final carboxylic acids such as fumaric (6), acetic (7) and oxalic (8) were detected and quantified by this technique. While the two former acids are oxidized to the latter one, acid 8 can be directly converted into $\mathrm{CO}_{2}[14,16]$. In the EF and PEF treatments, all these acids tend to form Fe(III) complexes, which are slowly oxidized by $\mathrm{BDD}\left({ }^{\bullet} \mathrm{OH}\right)$ and more difficultly attacked by ${ }^{\bullet} \mathrm{OH}$ in the bulk [37-40].

Low contents of acids 6 and $7(<0.017 \mathrm{mM})$ appeared up to 30-60 min in all treatments, as expected from the fast removal of these compounds and their Fe(III) complexes. In contrast, the final acid 8 was much more largely accumulated in all cases evidencing that it was the main carboxylic acid produced in the mineralization process. Fig. 6b shows a progressive accumulation with slow drop of acid 8 up to a final value of $0.13 \mathrm{mM}$ for $\mathrm{AO}-\mathrm{H}_{2} \mathrm{O}_{2}$. This value accounts for 3.1 $\mathrm{mg} \mathrm{L}^{-1}$ of TOC, which constitutes $11 \%$ of the organic load of the remaining solution (see Table 1 ). For EF and PEF, Fig. $6 \mathrm{~b}$ reveals that the much quicker destruction of primary intermediates by ${ }^{\bullet} \mathrm{OH}$ led to about $0.76-0.78 \mathrm{mM}$ of acid $\mathbf{8}$ as maximal at $60-90 \mathrm{~min}$, its further fall depending on the applied treatment. In EF, the slow oxidation of $\mathrm{Fe}(\mathrm{III})$-oxalate complexes by $\mathrm{BDD}\left({ }^{\bullet} \mathrm{OH}\right)$ yielded 
$0.39 \mathrm{mM}$ of final acid 8 , corresponding to $9.4 \mathrm{mg} \mathrm{L}^{-1}$ of TOC and a $47 \%$ of the organic load of the final solution (see Table 1). This means that the final solution of EF still contained 53\% of undetected products that are highly recalcitrant to hydroxyl radicals. On the other hand, the UVA light in PEF caused the quick and overall photodecarboxylation of Fe(III)-oxalate complexes via reaction (5), as highlighted in Fig. 6b, although a $2 \%$ of the starting TOC remained in the final solution (see Table 1). Consequently, the PEF process allows the oxidation of most of undetected recalcitrant products that cannot be destroyed by hydroxyl radicals in EF, thanks to the photolytic action of UVA radiation. This behavior along with the total removal of final carboxylic acids explains the almost total mineralization of trans-ferulic acid solutions achieved using the powerful PEF process.

\subsection{Plausible reaction pathway for trans-ferulic acid treated by EAOPs with BDD}

On the basis of the products detected by GC-MS and HPLC, a plausible reaction pathway is proposed in Fig. 7 for trans-ferulic acid mineralization by EAOPs with BDD anode. Oxidation of aromatics takes place via reaction with $\mathrm{BDD}\left({ }^{\bullet} \mathrm{OH}\right)$ in $\mathrm{AO}-\mathrm{H}_{2} \mathrm{O}_{2}$ and much more rapidly with ${ }^{\bullet} \mathrm{OH}$ in EF, PEF and SPEF, whereas that of final carboxylic acids and Fe(III)-carboxylate species involves preferentially the attack of $\mathrm{BDD}\left({ }^{\bullet} \mathrm{OH}\right)$. A much slower degradation with other generated oxidants like $\mathrm{H}_{2} \mathrm{O}_{2}, \mathrm{HO}_{2}{ }^{\bullet}, \mathrm{O}_{3}$ and $\mathrm{S}_{2} \mathrm{O}_{8}{ }^{2-}$ may occur as well. Only the fate of $\mathrm{Fe}(\mathrm{III})$ complexes with oxalic acid, but not of the other carboxylic acids, is stated for sake of simplicity.

The process starts with the decarboxylation of $\mathbf{1}$ to yield 2. Further oxidation of the side vinyl group of $\mathbf{2}$ yields $\mathbf{3}$ with a lateral ethyl group, which can then be oxidized either to the ketone $\mathbf{4}$ with demethylation or to the aldehyde 5. Subsequent degradation of all these aromatics with cleavage of the benzene ring leads to a mixture of final acids 6-8. Acids $\mathbf{6}$ and $\mathbf{7}$ are formed to a small extent and quickly converted into acid $\mathbf{8}$. This acid is directly transformed into $\mathrm{CO}_{2}$ by $\mathrm{BDD}\left({ }^{\circ} \mathrm{OH}\right)$ in $\mathrm{AO}-$ $\mathrm{H}_{2} \mathrm{O}_{2}$, but, in EF, PEF and SPEF, it forms Fe(III)-oxalate species that are slowly mineralized by 
$\mathrm{BDD}\left({ }^{\bullet} \mathrm{OH}\right)$ and much more rapidly photodecomposed under UVA light or sunlight, regenerating $\mathrm{Fe}^{2+}$ according to reaction (5).

\section{Conclusions}

The PEF treatment of trans-ferulic acid solutions of $\mathrm{pH} 3.0$ is able to yield almost total mineralization with $98 \%$ TOC reduction for substrate contents $\geq 0.843 \mathrm{mM}$ and $j \geq 16.7 \mathrm{~mA} \mathrm{~cm}^{-2}$. It is much powerful than EF, which allowed 92\% TOC abatement as maximal at $100 \mathrm{~mA} \mathrm{~cm}^{-2}$, because of the enhancement of the destruction of highly recalcitrant products to hydroxyl radicals by UVA irradiation. The oxidation ability of $\mathrm{AO}-\mathrm{H}_{2} \mathrm{O}_{2}$ was slightly lower than that of EF up to $0.843 \mathrm{mM}$ trans-ferulic acid and $j=33.3 \mathrm{~mA} \mathrm{~cm}^{-2}$, both methods possessing similar mineralization power for higher substrate concentrations and $j$ values. The decay of trans-ferulic acid concentration by $\mathrm{AO}-\mathrm{H}_{2} \mathrm{O}_{2}$ was very slow by its poor reaction with $\mathrm{BDD}\left({ }^{\bullet} \mathrm{OH}\right)$, being much faster in EF and PEF due to its much quicker reaction with ${ }^{\bullet} \mathrm{OH}$ in the bulk. For each EAOP, increasing $j$ from 16.7 to $100 \mathrm{~mA} \mathrm{~cm}{ }^{-2}$ caused faster mineralization with lower MCE, whereas the change of substrate concentration from 0.167 to $1.668 \mathrm{mM}$ gave similar percentage of final TOC removed with a concomitant growth of current efficiency. The SPEF treatment accelerated the mineralization compared with PEF, although it also promoted the accumulation of a slightly larger proportion of barely oxidizable products. Four aromatic products and three short carboxylic acids were identified. Oxalic acid was the most important product and its total disappearance in PEF in contrast to its large persistence in $\mathrm{AO}-\mathrm{H}_{2} \mathrm{O}_{2}$ and EF explained the superior oxidation power of the former EAOP.

\section{Acknowledgments}

The authors thank MINECO (Spain) for financial support under project CTQ2013-48897-C2-1R, co-financed with FEDER funds. The Ph.D. fellowship awarded to N. Flores from SENESCYT (Ecuador) is also acknowledged. 


\section{References}

[1] U.T. Un, U. Altay, A.S. Koparal, U.B. Ogutveren, Complete treatment of olive mill wastewaters by electrooxidation, Chem. Eng. J. 139 (2008) 445-452.

[2] S. Magdich, C. Ben Ahmed, R. Jarboui, B. Ben Rouina, M. Boukhris, E. Ammar, Dose and frequency dependent effects of olive mill wastewater treatment on the chemical and microbial properties of soil, Chemosphere 93 (2013) 1896-1903.

[3] S. Dermeche, M. Nadour, C. Larroche, F. Moulti-Mati, P. Michaud, Olive mill wastes: Biochemical characterizations and valorization strategies, Process Biochem. 48 (2013) 15321552.

[4] J.M. Ochando-Pulido, M.D. Victor-Ortega, G. Hodaifa, A. Martinez-Ferez, Physicochemical analysis and adequation of olive oil mill wastewater after advanced oxidation process for reclamation by pressure-driven membrane technology, Sci. Total Environ. 503-504 (2014) 113-121.

[5] M. DellaGreca, L. Previtera, F. Temussi, A. Zarrelli, Low-molecular-weight components of olive oil mill waste-waters, Phytochem. Anal. 15 (2004) 184-188.

[6] C. Mancuso, R. Santangelo, Ferulic acid: Pharmacological and toxicological aspects, Food Chem. Toxicol. 65 (2014) 185-195.

[7] N. Kumar, V. Pruthi, Potential applications of ferulic acid from natural sources, Biotechnol. Reports 4 (2014) 86-93.

[8] M.A. Miranda, F. Galindo, A.M. Amat, A. Arques, Pyrylium salt-photosensitized degradation of phenolic contaminants derived from cinnamic acid with solar light. Correlation of the observed reactivities with fluorescence quenching, Appl. Catal. B: Environ. 28 (2000) 127133. 
[9] B.R. Yadav, A. Garg, Catalytic wet oxidation of ferulic acid (a lignin model compound) in the presence of non-noble metal based catalysts at mild conditions, Chem. Eng. J. 252 (2014) 185-193.

[10] R. Andreozzi, M. Canterino, V. Caprio, I. Di Somma, R. Marotta, Use of an amorphous iron oxide hydrated as catalyst for hydrogen peroxide oxidation of ferulic acid in water, J. Hazard. Mater. 152 (2008) 870-875.

[11] V. Augugliaro, G. Camera-Roda, V. Loddo, G. Palmisano, L. Palmisano, F. Parrino, Synthesis of vanillin in water by $\mathrm{TiO}_{2}$ photocatalysis, Appl. Catal. B: Environ. 111-112 (2012) 555-561.

[12] M. Panizza, G. Cerisola, Direct and mediated anodic oxidation of organic pollutants, Chem. Rev. 109 (2009) 6541-6569.

[13] I. Sirés, E. Brillas, Remediation of water pollution caused by pharmaceutical residues based on electrochemical separation and degradation technologies: a review, Environ. Int. 40 (2012) 212-229.

[14] I. Sirés, E. Brillas, M.A. Oturan, M.A. Rodrigo, M. Panizza, Electrochemical advanced oxidation processes: today and tomorrow. A review, Environ. Sci. Pollut. Res. 21 (2014) 8336-8367.

[15] S. Vasudevan, M.A. Oturan, Electrochemistry: As cause and cure in water pollution-an overview, Environ. Chem. Lett. 12 (2014) 97-108.

[16] E. Brillas, C.A. Martínez-Huitle, Decontamination of wastewaters containing synthetic organic dyes by electrochemical methods. An updated review, Appl. Catal. B: Environ. 166167 (2015) 603-643.

[17] B. Boye, P.A. Michaud, B. Marselli, M.M. Dieng, E. Brillas, C. Comninellis, Anodic oxidation of 4-chlorophenoxyacetic acid on synthetic boron-doped diamond electrodes, New Diamond Front. Carbon Technol. 12 (2002) 63-72. 
[18] B. Marselli, J. Garcia-Gomez, P.A. Michaud, M.A. Rodrigo, C. Comninellis, Electrogeneration of hydroxyl radicals on boron-doped diamond electrodes, J. Electrochem. Soc. 150 (2003) D79-D83.

[19] C.A. Martínez-Huitle, S. Ferro, Electrochemical oxidation of organic pollutants for the wastewater treatment: direct and indirect processes, Chem. Soc. Rev. 35 (2006) 1324-1340.

[20] M. Hamza, R. Abdelhedi, E. Brillas, I. Sirés, Comparative electrochemical degradation of the triphenylmethane dye Methyl Violet with boron-doped diamond and Pt anodes, J. Electroanal. Chem. 627 (2009) 41-50.

[21] L. Ciríaco, C. Anjo, J. Correia, M.J. Pacheco, A. Lopes, Electrochemical degradation of ibuprofen on Ti/Pt/PbO 2 and Si/BDD electrodes, Electrochim. Acta 54 (2009) 1464-1472.

[22] M.A. Rodrigo, P. Cañizares, A. Sánchez-Carretero, C. Sáez, Use of conductive-diamond electrochemical oxidation for wastewater treatment, Catal. Today 151 (2010) 173-177.

[23] E.B. Cavalcanti, S. Garcia-Segura, F. Centellas, E. Brillas, Electrochemical incineration of omeprazole in neutral aqueous medium using a platinum or boron-doped diamond. Degradation kinetics and oxidation products, Water Res. 47 (2013) 1803-1815.

[24] A. Wang, J. Qu, H. Liu, J. Ru, Mineralization of an azo dye Acid Red 14 by photoelectroFenton process using an activated carbon fiber cathode, Appl. Catal. B: Environ. 84 (2008) 393-399.

[25] A. Khataee, A. Khataee, M. Fathinia, B. Vahid, S.W. Joo, Kinetic modeling of photoassistedelectrochemical process for degradation of an azo dye using boron-doped diamond anode and cathode with carbon nanotubes, J. Ind. Eng. Chem. 19 (2013) 1890-1894.

[26] A. Khataee, A. Akbarpour, B. Vahi, Photoassisted electrochemical degradation of an azo dye using $\mathrm{Ti} / \mathrm{RuO}_{2}$ anode and carbon nanotubes containing gas-diffusion cathode, J. Taiwan Inst. Chem. Eng. 45 (2014) 930-936. 
[27] V. Vatanpour, N. Daneshvar, M.H. Rasoulifard, Electro-Fenton degradation of synthetic dye mixture: influence of intermediates, J. Environ. Eng. Manage. 19 (2009) 277-282.

[28] M.H.M.T. Assumpção, A. Moraes, R.F.B. De Souza, R.M. Reis, R.S. Rocha, I. Gaubeur, M.L. Calegaro, P. Hammer, M.R.V. Lanza, M.C. Santos, Degradation of dipyrone via advanced oxidation processes using a cerium nanostructured electrocatalyst material, Appl. Catal. A: Gen. 462-463 (2013) 256-261.

[29] A. Dirany, I. Sirés, N. Oturan, A. Özcan, M.A. Oturan, Electrochemical treatment of the antibiotic sulfachloropyridazine: kinetics, reaction pathways, and toxicity evolution. Environ. Sci. Technol. 46 (2012) 4074-4082.

[30] M.S. Yahya, N. Oturan, K. El Kacemi, M. El Karbane, C.T. Aravindakumar, M.A. Oturan, Oxidative degradation study on antimicrobial agent ciprofloxacin by electro-Fenton process: Kinetics and oxidation products, Chemosphere 117 (2014) 447-454.

[31] A. El-Ghenymy, R.M. Rodríguez, E. Brillas, N. Oturan, M.A. Oturan, Electro-Fenton degradation of the antibiotic sulfanilamide with Pt/carbon-felt and BDD/carbon-felt cells. Kinetics, reaction intermediates, and toxicity assessment, Environ. Sci. Pollut. Res. 21 (2014) 8368-8378.

[32] S. Ammar, R. Abdelhedi, C. Flox, C. Arias, E. Brillas, Electrochemical degradation of the dye indigo carmine at boron-doped diamond anode for wastewaters remediation, Environ. Chem. Lett. 4 (2006) 229-233.

[33] A. Thiam, M. Zhou, E. Brillas, I. Sirés, Two-step mineralization of Tartrazine solutions: Study of parameters and by-products during the coupling of electrocoagulation with electrochemical advanced oxidation processes, Appl. Catal. B: Environ. 150-151 (2014) 116125. 
[34] A. Thiam, I. Sirés, J.A. Garrido, R.M. Rodríguez, E. Brillas, Decolorization and mineralization of Allura Red AC aqueous solutions by electrochemical advanced oxidation processes, J. Hazard. Mater. 290 (2015) 34-42.

[35] K. Cruz-González, O. Torres-López, A. García-León, J.L. Guzmán-Mar, L.H. Reyes, A. Hernández-Ramírez, J.M. Peralta-Hernández, Determination of optimum operating parameters for Acid Yellow 36 decolorization by electro-Fenton process using BDD cathode, Chem. Eng. J. 160 (2010) 199-206.

[36] K. Cruz-González, O. Torres-López, A. García-León, E. Brillas, A. Hernández-Ramírez, J.M. Peralta-Hernández, Optimization of electro-Fenton/BDD process for decolorization of a model azo dye wastewater by means of response surface methodology, Desalination 286 (2012) 63-68.

[37] E.J. Ruiz, A. Hernández-Ramírez, J.M. Peralta-Hernández, C. Arias, E. Brillas, Application of solar photoelectro-Fenton technology to azo dyes mineralization: Effect of current density, $\mathrm{Fe}^{2+}$ and dye concentrations, Chem. Eng. J. 171 (2011) 385-392.

[38] F.C. Moreira, S. Garcia-Segura, V.J.P. Vilar, R.A.R. Boaventura, E. Brillas, Decolorization and mineralization of Sunset Yellow FCF azo dye by anodic oxidation, electro-Fenton, UVA photoelectro-Fenton and solar photoelectro-Fenton processes, Appl. Catal. B: Environ. 142143 (2013) 877-890.

[39] X. Florenza, A.M.S. Solano, F. Centellas, C.A. Martínez-Huitle, E. Brillas, S. Garcia-Segura, Degradation of the azo dye Acid Red 1 by anodic oxidation and indirect electrochemical processes based on Fenton's reaction chemistry. Relationship between decolorization, mineralization and products, Electrochim. Acta 142 (2014) 276-288.

[40] A. Thiam, I. Sirés, F. Centellas, P.L. Cabot, E. Brillas, Decolorization and mineralization of Allura Red AC azo dye by solar photoelectro-Fenton: Identification of intermediates, Chemosphere 136 (2015) 1-8. 
[41] B. Boye, M.M. Dieng, E. Brillas, Electrochemical degradation of 2,4,5trichlorophenoxyacetic acid in aqueous medium by peroxi-coagulation. Effect of $\mathrm{pH}$ and $\mathrm{UV}$ light, Electrochim. Acta 48 (2003) 781-790. 


\section{Figure captions}

Fig. 1. Variation of trans-ferulic acid concentration with electrolysis time for the degradation of 100 $\mathrm{mL}$ of a $0.834 \mathrm{mM}$ substrate solution in $0.05 \mathrm{M} \mathrm{Na}_{2} \mathrm{SO}_{4}$ at $\mathrm{pH} 3.0$ and $35{ }^{\circ} \mathrm{C}$ using a BDD/airdiffusion cell of $3 \mathrm{~cm}^{2}$ electrode area by applying $33.3 \mathrm{~mA} \mathrm{~cm}$. . In (a), anodic oxidation with electrogenerated $\mathrm{H}_{2} \mathrm{O}_{2}\left(\mathrm{AO}-\mathrm{H}_{2} \mathrm{O}_{2}\right)$. In (b), $(\triangle)$ electro-Fenton (EF) with addition of $0.50 \mathrm{mM} \mathrm{Fe}{ }^{2+}$ and $(\boldsymbol{\Delta})$ photoelectro-Fenton $(\mathrm{PEF})$ with addition of $0.50 \mathrm{mM} \mathrm{Fe} \mathrm{F}^{2+}$ using a $6 \mathrm{~W}$ UVA light. The inset panels depict the pseudo-first-order kinetics found for the trans-ferulic acid content abatement.

Fig. 2. Change of (a) TOC and (b) mineralization current efficiency with electrolysis time under the same conditions of Fig. 1. Method: $(\mathrm{O}) \mathrm{AO}-\mathrm{H}_{2} \mathrm{O}_{2},(\triangle) \mathrm{EF}$ and $(\mathbf{\Delta}) \mathrm{PEF}$.

Fig. 3. Influence of current density on (a) TOC decay and (b) mineralization current efficiency vs. electrolysis time for the PEF treatment of $100 \mathrm{~mL}$ of a $0.834 \mathrm{mM}$ trans-ferulic acid solution in 0.05 $\mathrm{M} \mathrm{Na}_{2} \mathrm{SO}_{4}$ with $0.50 \mathrm{mM} \mathrm{Fe}{ }^{2+}$ at $\mathrm{pH} 3.0$ and $35^{\circ} \mathrm{C}$ using a BDD/air-diffusion cell. Applied current density: (○) $16.7 \mathrm{~mA} \mathrm{~cm}^{-2},(\boldsymbol{\Delta}) 33.3 \mathrm{~mA} \mathrm{~cm}^{-2},(\bullet) 66.7 \mathrm{~mA} \mathrm{~cm}^{-2}$ and $(\boldsymbol{\nabla}) 100 \mathrm{~mA} \mathrm{~cm}^{-2}$.

Fig. 4. Effect of trans-ferulic acid concentration on (a) TOC removal and (b) mineralization current efficiency vs. electrolysis time for the PEF degradation of $100 \mathrm{~mL}$ of solutions of this substrate in $0.05 \mathrm{M} \mathrm{Na}_{2} \mathrm{SO}_{4}$ with $0.50 \mathrm{mM} \mathrm{Fe}^{2+}$ at $\mathrm{pH} 3.0$ using a BDD/air-diffusion cell at $33.3 \mathrm{~mA} \mathrm{~cm}{ }^{-2}$ and 35 ${ }^{\circ} \mathrm{C}$. Content of trans-ferulic acid: $(\boldsymbol{\bullet}) 0.167 \mathrm{mM},(\bullet) 0.417 \mathrm{mM},(\mathbf{\Delta}) 0.834 \mathrm{mM}$ and $(\boldsymbol{\square}) 1.668 \mathrm{mM}$.

Fig. 5. Variation of: (a) TOC and (b) mineralization current efficiency with electrolysis time for the solar PEF (SPEF) degradation of $100 \mathrm{~mL}$ of trans-ferulic acid solutions in $0.05 \mathrm{M} \mathrm{Na}_{2} \mathrm{SO}_{4}$ with 0.50 $\mathrm{mM} \mathrm{Fe}{ }^{2+}$ at $\mathrm{pH} 3.0$ and $35{ }^{\circ} \mathrm{C}$ using a BDD/air-diffusion cell. Content of trans-ferulic acid: $0.834 \mathrm{mM}$ and $(\diamond) 0.417 \mathrm{mM}$. Current density: $(\boldsymbol{\square}, \diamond) 33.3 \mathrm{~mA} \mathrm{~cm}^{-2}$ and $(\boldsymbol{\nabla}) 100 \mathrm{~mA} \mathrm{~cm}{ }^{-2}$.

Fig. 6. Time-course of the concentration of (a) vanillin (5) and (b) oxalic acid (8) detected during the treatments shown in Fig. 1. Method: (O) AO- $\mathrm{H}_{2} \mathrm{O}_{2},(\triangle)$ EF and $(\boldsymbol{\Delta})$ PEF. 
Fig. 7. Reaction pathway proposed for trans-ferulic acid mineralization by $\mathrm{AO}-\mathrm{H}_{2} \mathrm{O}_{2}, \mathrm{EF}$, PEF and SPEF using a BDD/air-diffusion cell. The species ${ }^{\bullet} \mathrm{OH}$ in the sequence of aromatics accounts for by their oxidation by $\mathrm{BDD}\left({ }^{\bullet} \mathrm{OH}\right)$ at the $\mathrm{BDD}$ surface and/or ${ }^{\bullet} \mathrm{OH}$ from Fenton’s reaction in the bulk. 


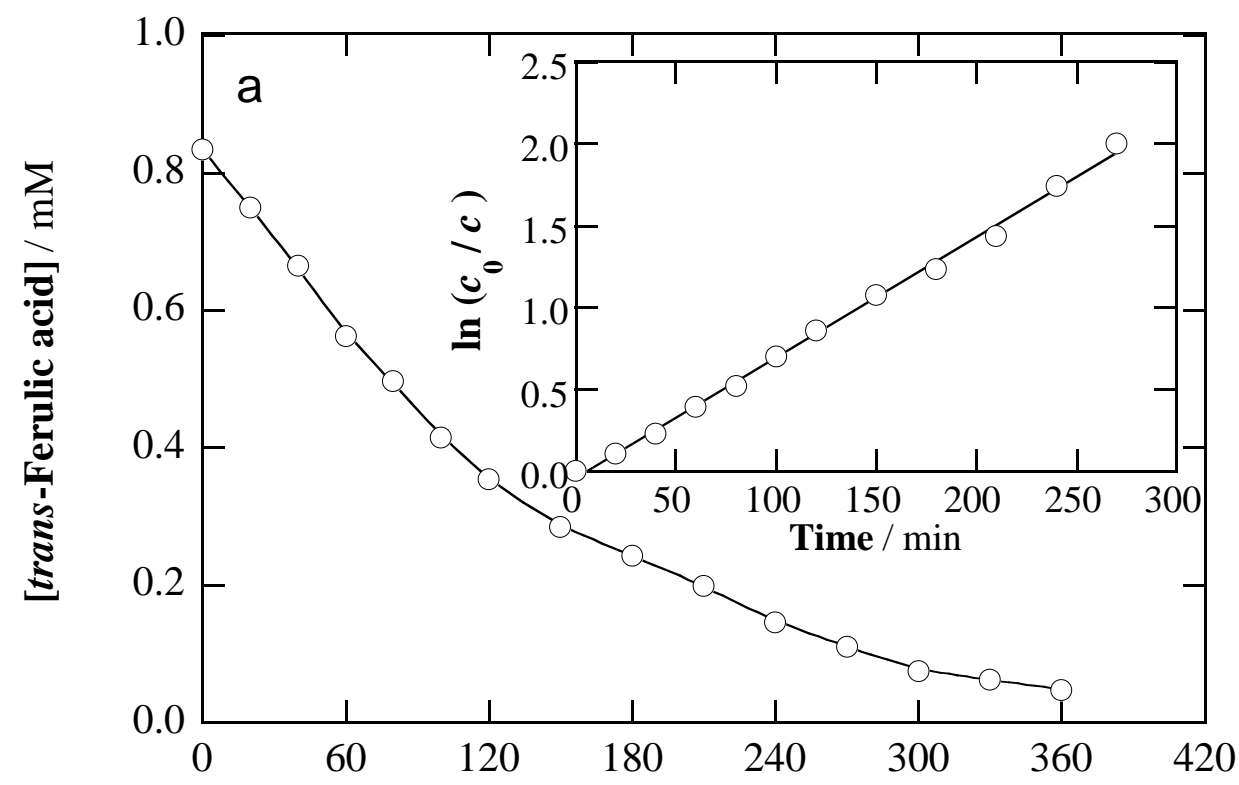

Time / min

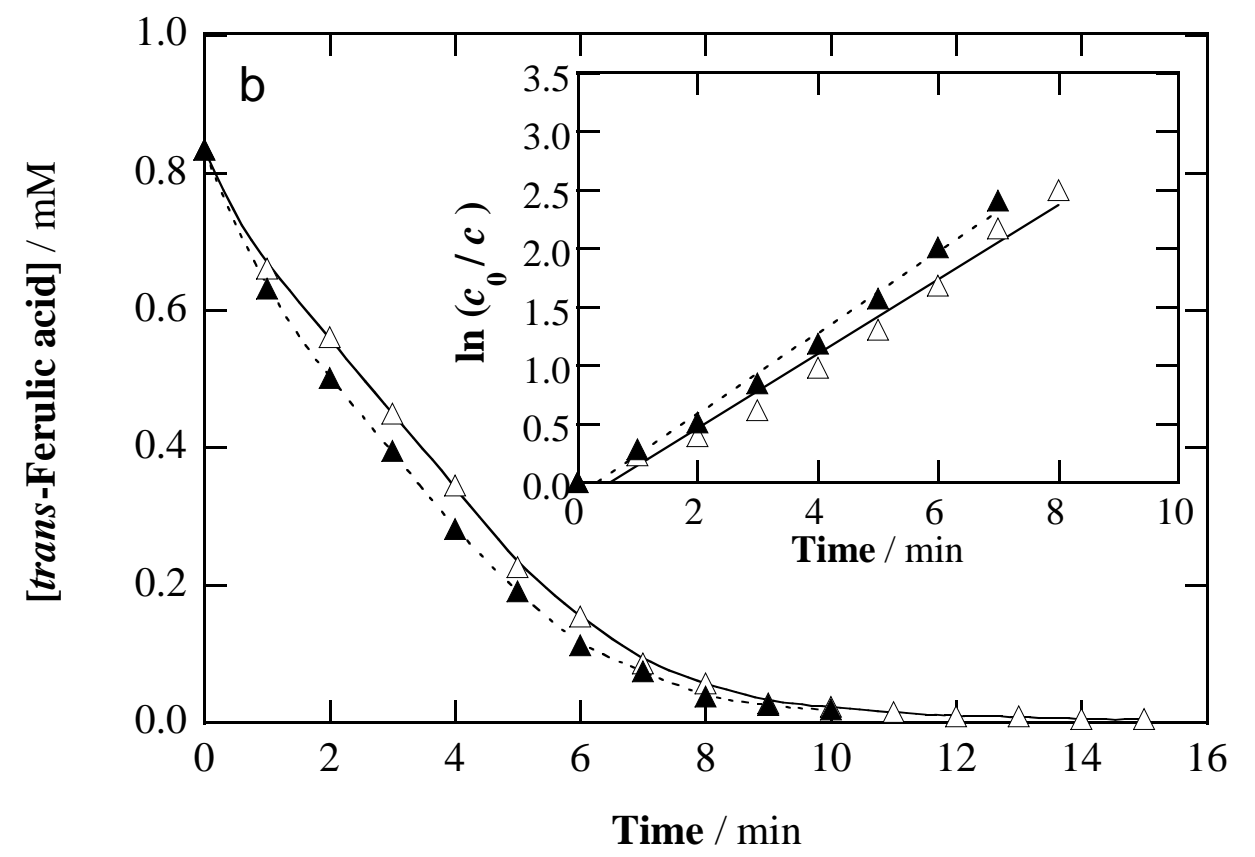

Fig. 1 


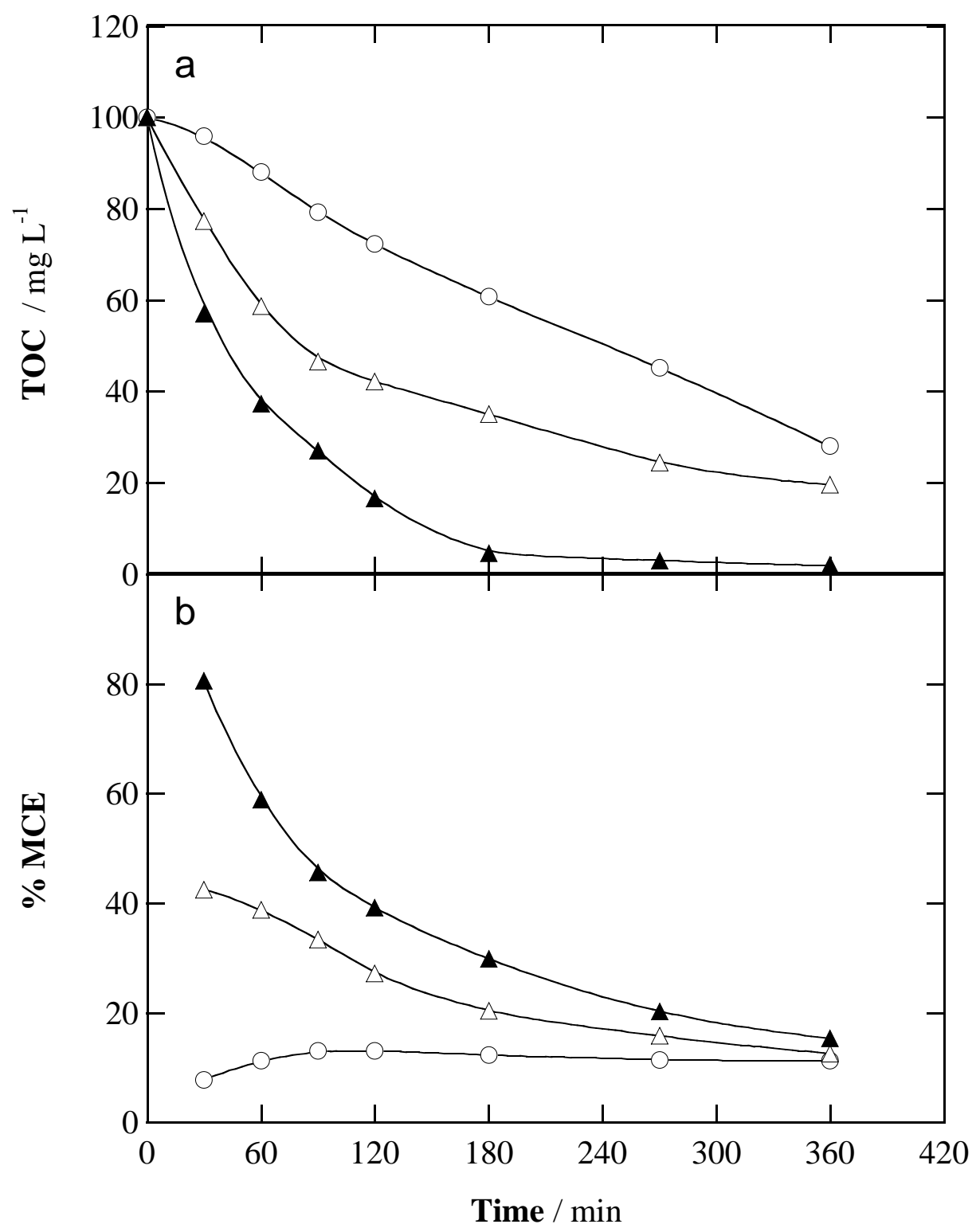

Fig. 2 


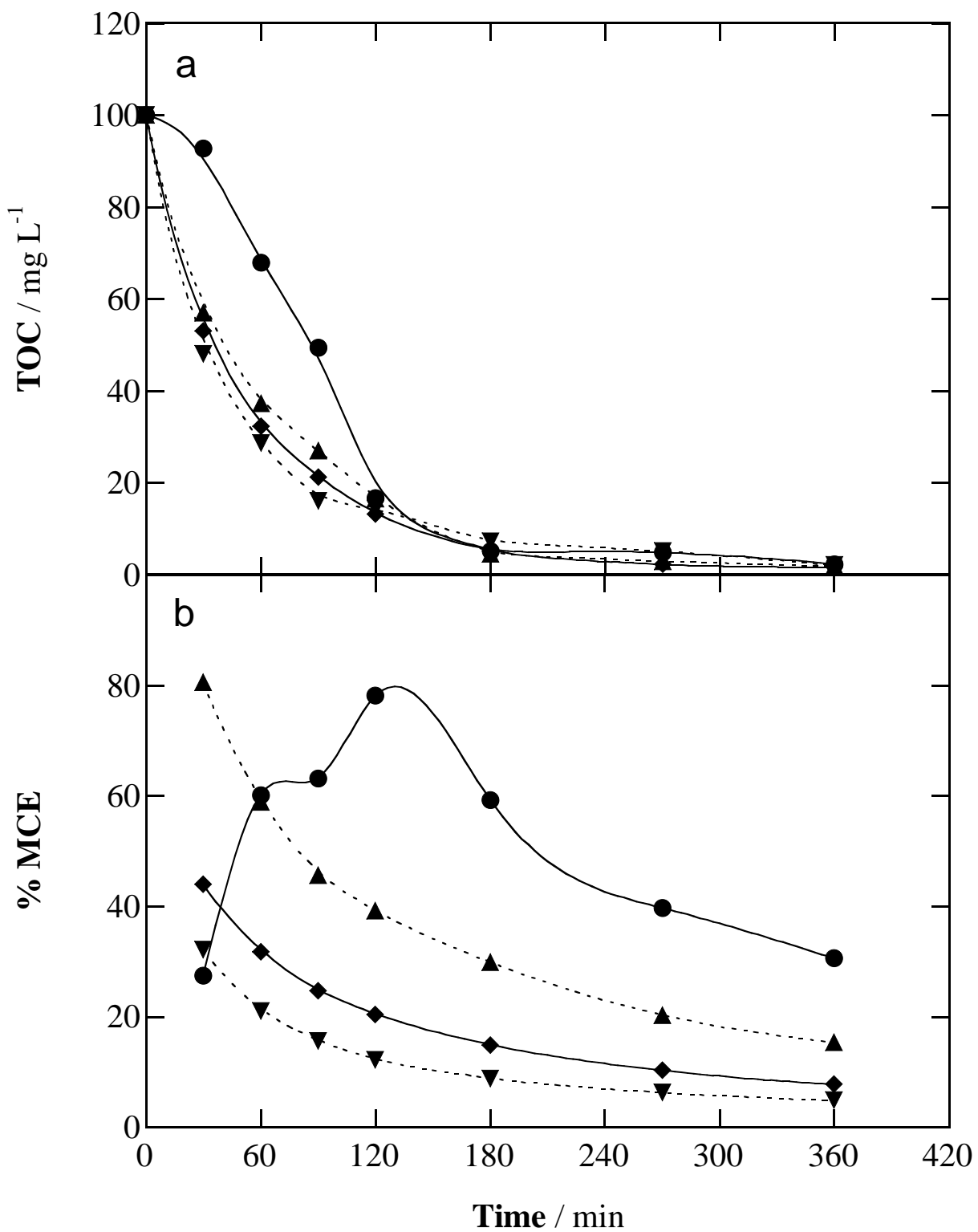

Fig. 3 


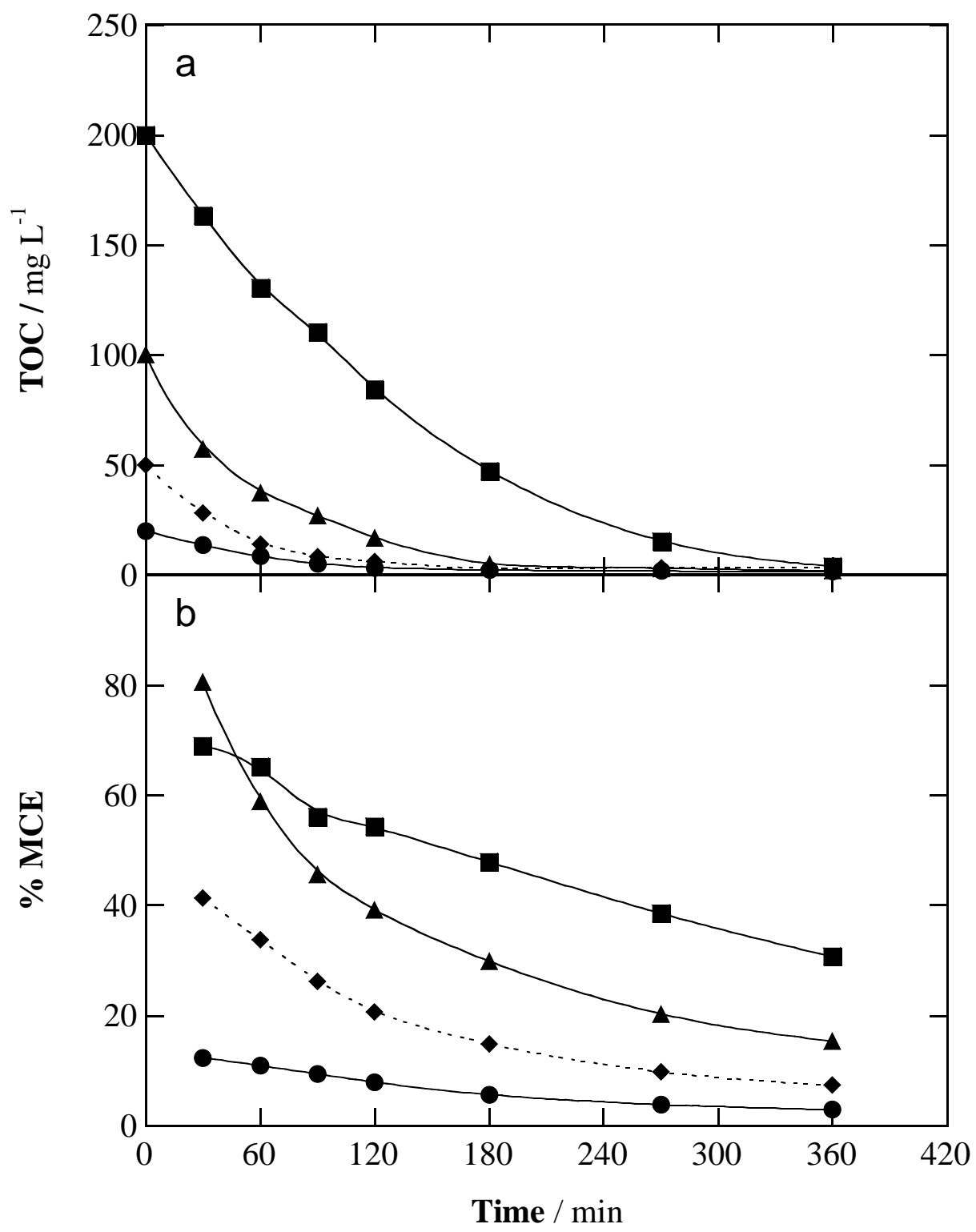

Fig. 4 


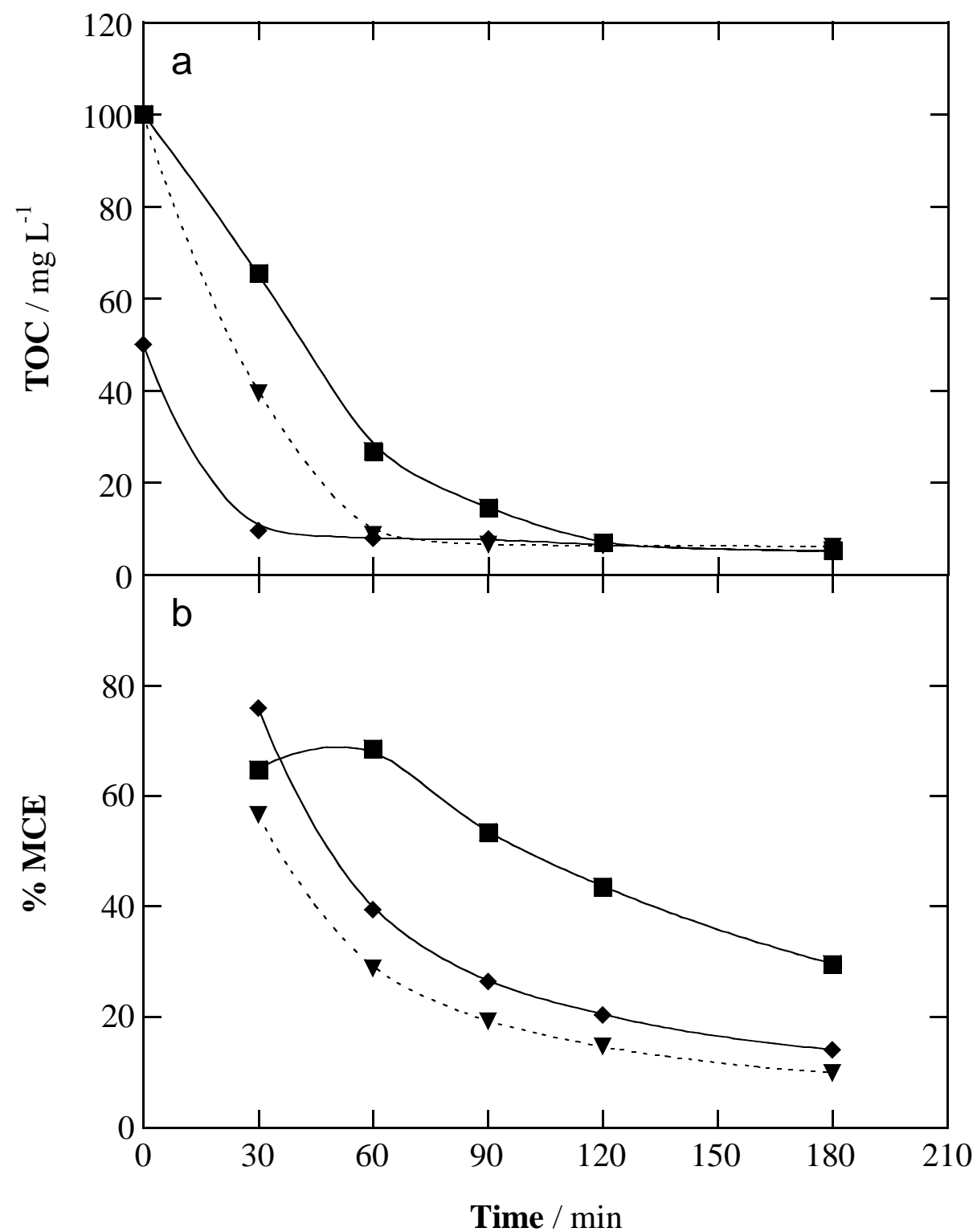

Fig. 5 


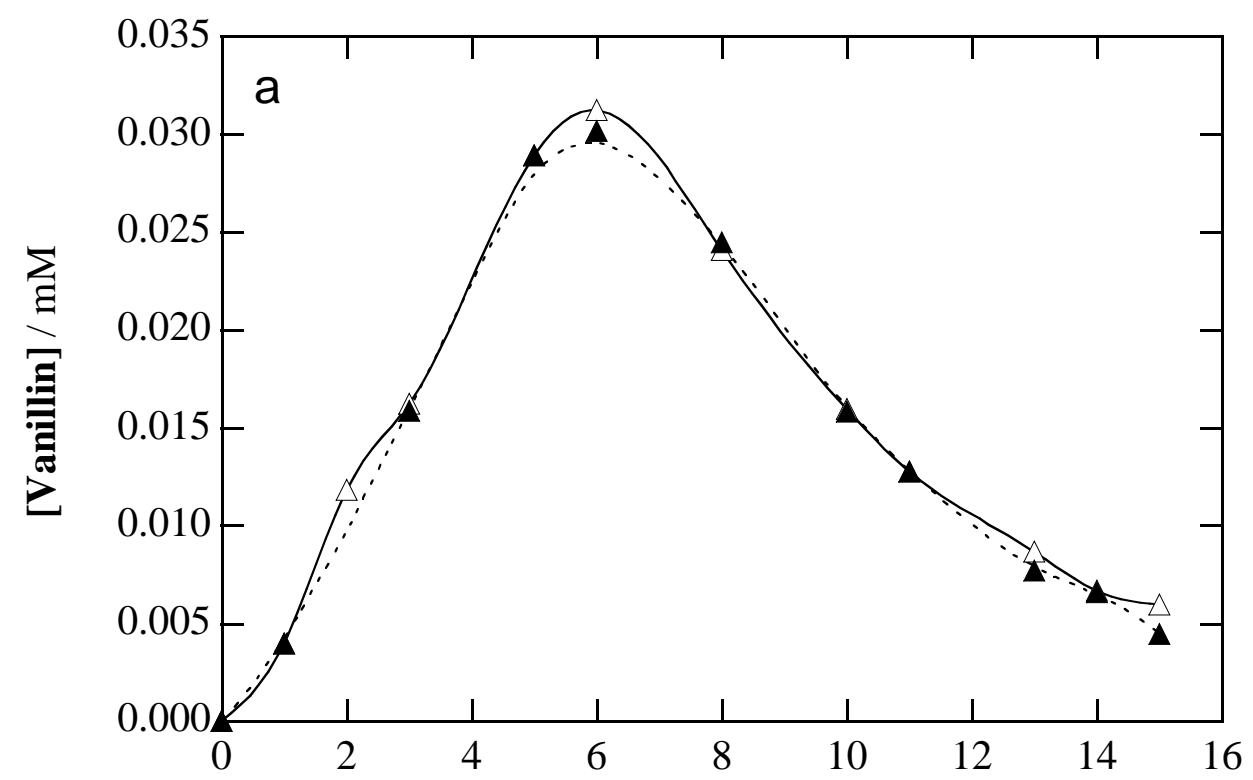

Time / min

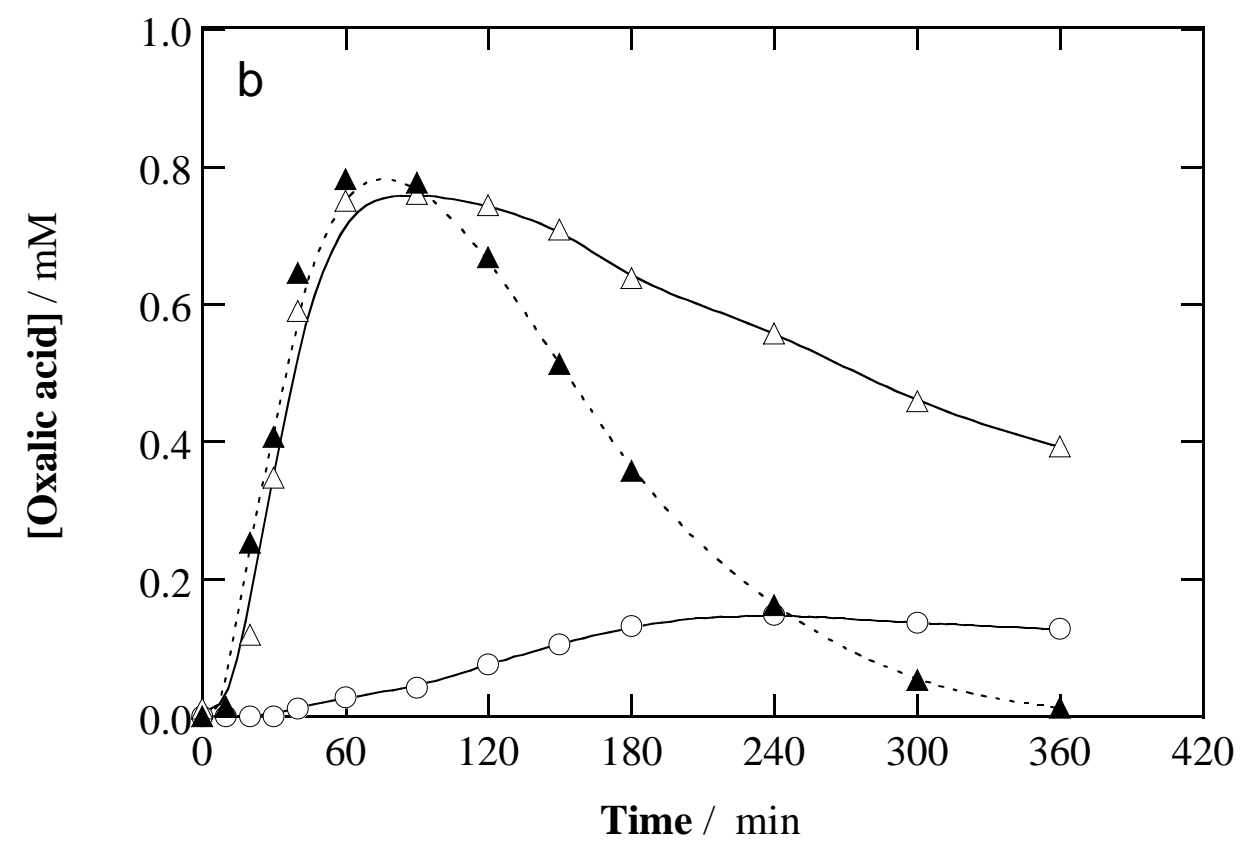

Fig. 6 


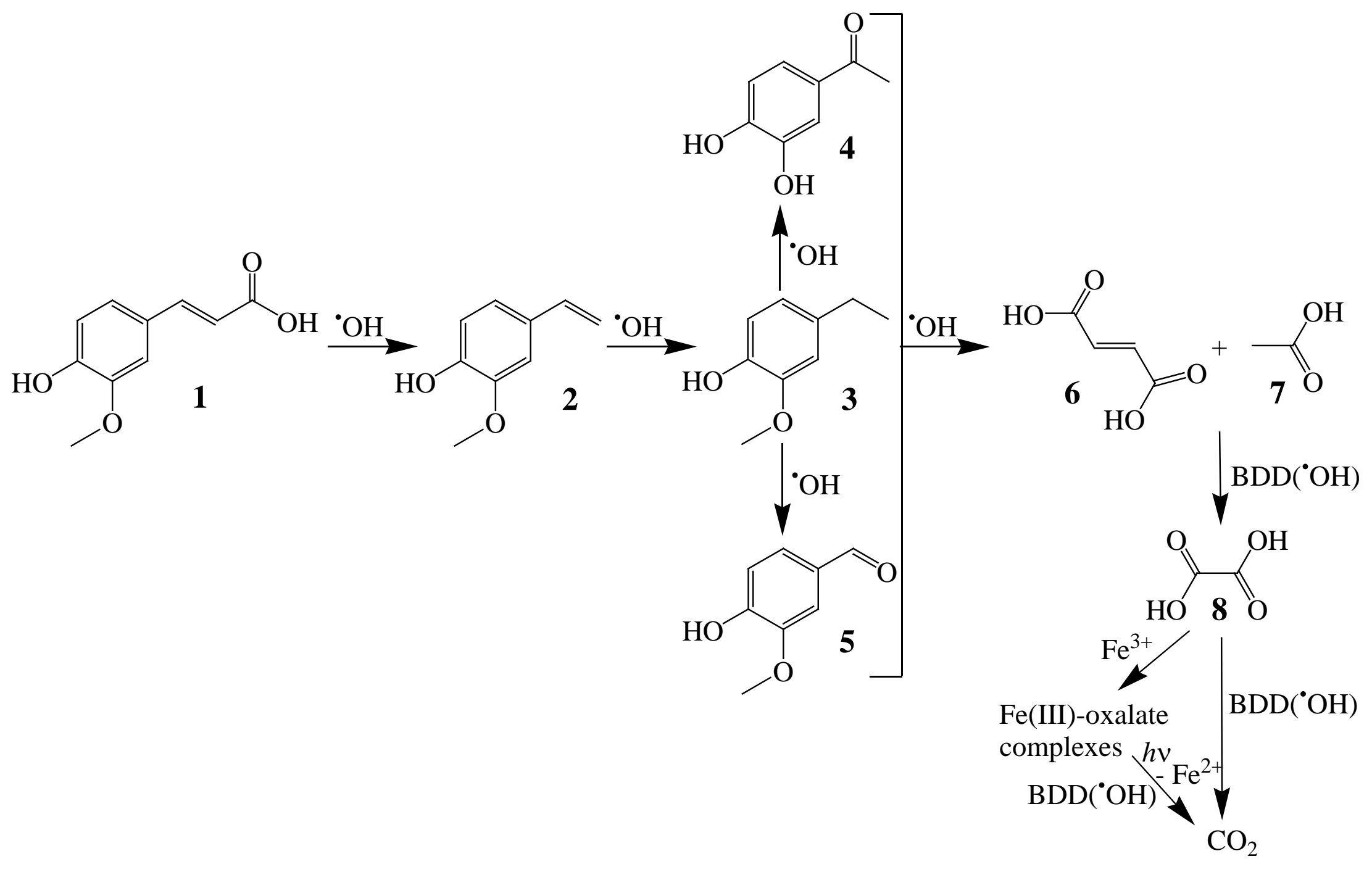

Fig. 7 
Table 1.

Pseudo-first-order rate constant for trans-ferulic acid decay, along with its square regression coefficient, and percentage of TOC removed and mineralization current efficiency at $360 \mathrm{~min}$ determined for the degradation of $100 \mathrm{~mL}$ of solutions of this compound in $0.05 \mathrm{M} \mathrm{Na}_{2} \mathrm{SO}_{4}$ at $\mathrm{pH} 3.0$ and $35{ }^{\circ} \mathrm{C}$ by electrochemical advanced oxidation methods using a stirred BDD/air-diffusion cell under different experimental conditions.

\begin{tabular}{|c|c|c|c|c|c|c|}
\hline Method & $\begin{array}{c}\text { [trans-ferulic acid] } \\
(\mathrm{mM})\end{array}$ & $\begin{array}{l}\text { Current } \\
\text { density } \\
\left(\mathrm{mA} \mathrm{cm}^{-2}\right)\end{array}$ & $\begin{array}{c}k_{1} \\
\left(\mathrm{~min}^{-1}\right)\end{array}$ & $R^{2}$ & $\begin{array}{c}\% \text { TOC } \\
\text { removed } \\
\text { at } 360 \text { min }\end{array}$ & $\begin{array}{l}\% \mathrm{MCE} \\
\text { at } 360 \mathrm{~min}\end{array}$ \\
\hline \multirow[t]{7}{*}{$\mathrm{AO}-\mathrm{H}_{2} \mathrm{O}_{2}$} & 0.167 & 33.3 & $(0.82 \pm 0.03) \times 10^{-2}$ & 0.993 & 74 & 2.3 \\
\hline & 0.417 & 33.3 & $(0.74 \pm 0.03) \times 10^{-2}$ & 0.989 & 68 & 5.3 \\
\hline & 0.834 & 16.7 & & & 62 & 19 \\
\hline & & 33.3 & $(0.72 \pm 0.01) \times 10^{-2}$ & 0.997 & 72 & 11 \\
\hline & & 66.7 & & & 88 & 6.9 \\
\hline & & 100 & & & 94 & 4.9 \\
\hline & 1.668 & 33.3 & & & 67 & 21 \\
\hline \multirow[t]{7}{*}{$\mathrm{EF}^{\mathrm{a}}$} & 0.167 & 33.3 & $0.87 \pm 0.05$ & 0.990 & 75 & 2.4 \\
\hline & 0.417 & 33.3 & $0.70 \pm 0.04$ & 0.993 & 77 & 6.0 \\
\hline & 0.834 & 16.7 & & & 74 & 23 \\
\hline & & 33.3 & $0.32 \pm 0.02$ & 0.990 & 80 & 13 \\
\hline & & 66.7 & & & 87 & 6.7 \\
\hline & & 100 & & & 92 & 4.8 \\
\hline & 1.668 & 33.3 & & & 74 & 23 \\
\hline \multirow[t]{7}{*}{$\mathrm{PEF}^{\mathrm{b}}$} & 0.167 & 33.3 & $0.88 \pm 0.06$ & 0.988 & 92 & 2.9 \\
\hline & 0.417 & 33.3 & $0.69 \pm 0.03$ & 0.993 & 94 & 7.3 \\
\hline & 0.834 & 16.7 & & & 98 & 31 \\
\hline & & 33.3 & $0.34 \pm 0.02$ & 0.991 & 98 & 15 \\
\hline & & 66.7 & & & 98 & 7.7 \\
\hline & & 100 & & & 98 & 5.1 \\
\hline & 1.668 & 33.3 & & & 98 & 31 \\
\hline
\end{tabular}

${ }^{\mathrm{a}}$ With addition of $0.50 \mathrm{mM} \mathrm{Fe} \mathrm{H}^{2+}$

${ }^{\mathrm{b}}$ With addition of $0.50 \mathrm{mM} \mathrm{Fe}{ }^{2+}$ and irradiation with a $6 \mathrm{~W}$ UVA light $\left(\lambda_{\max }=360 \mathrm{~nm}\right)$. 
Table 2.

Aromatic products identified by GC-MS during the electrolysis of $100 \mathrm{~mL}$ of a $0.834 \mathrm{mM}$ transferulic acid solution in $0.05 \mathrm{M} \mathrm{Na}_{2} \mathrm{SO}_{4}$ at $\mathrm{pH} 3.0$ and $35{ }^{\circ} \mathrm{C}$ by $\mathrm{AO}-\mathrm{H}_{2} \mathrm{O}_{2}$ using a stirred BDD/airdiffusion cell at $33.3 \mathrm{~mA} \mathrm{~cm}{ }^{-2}$.

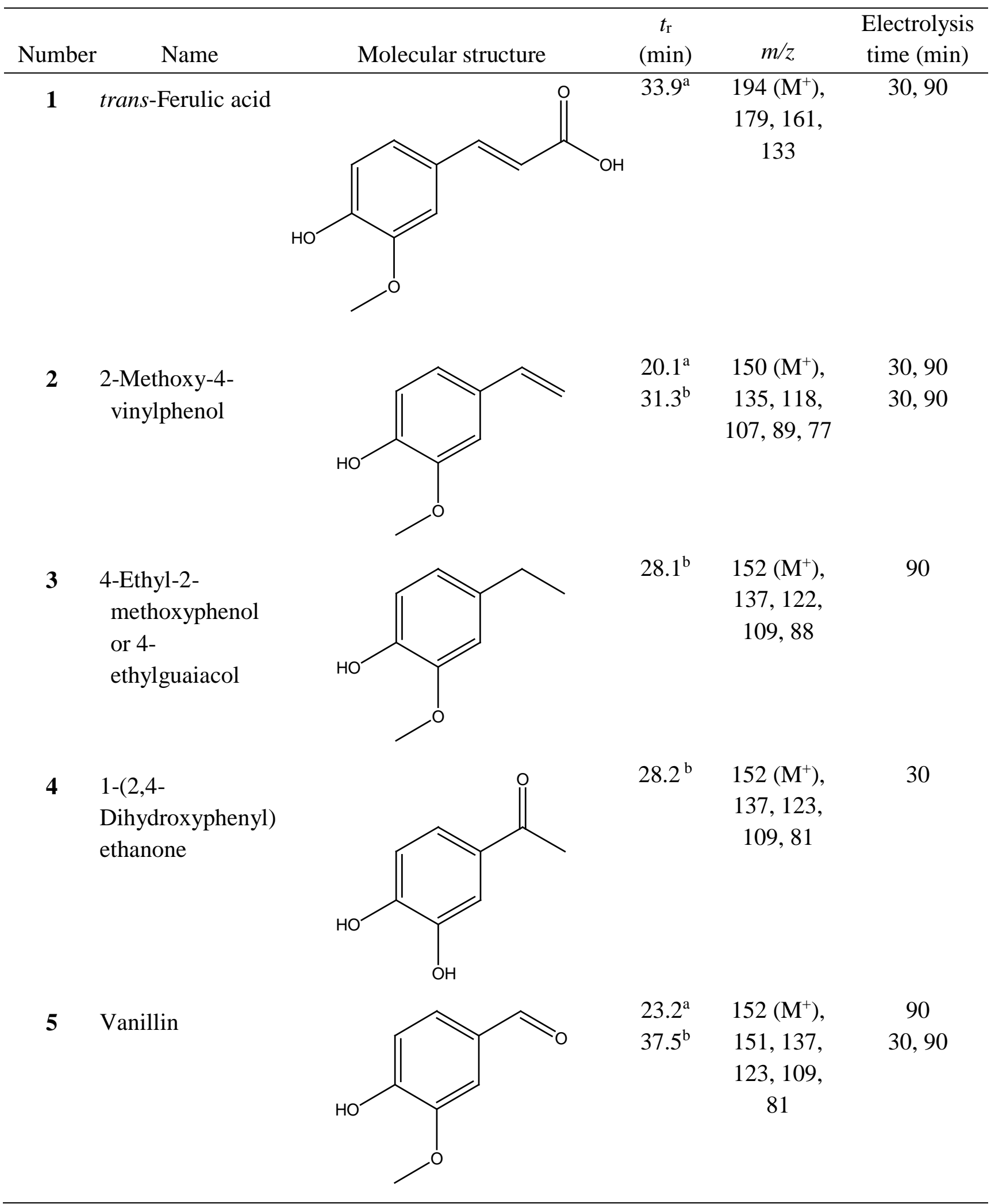

Retention times for: ${ }^{\mathrm{a}}$ non-polar Agilent J\&W HP-5ms and ${ }^{\mathrm{b}}$ polar HP INNOWax columns. 